Journal of

Business and Strategic

Management

(JBSM)

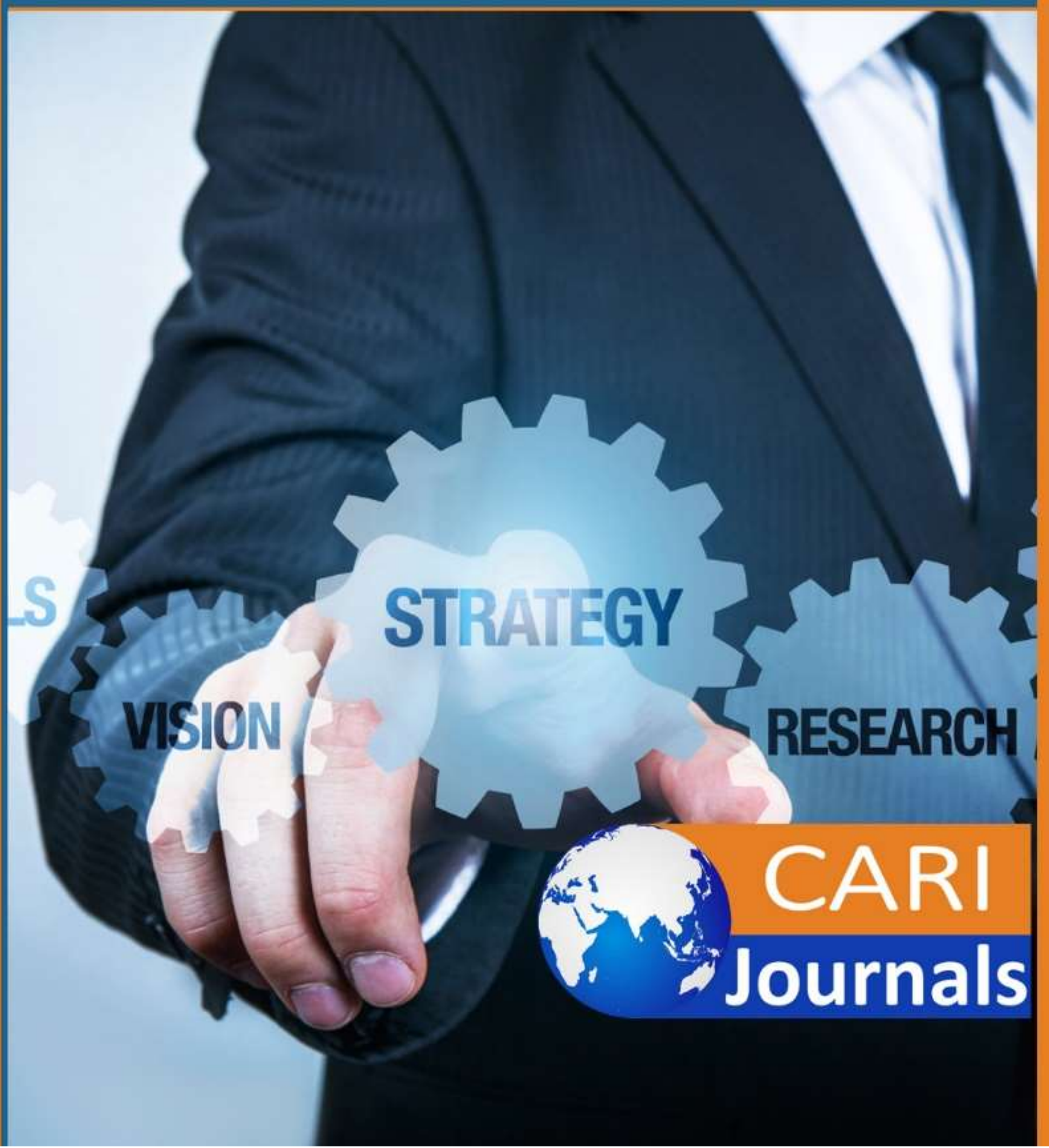




\title{
STRATEGIC ALLIANCES AND THE FINANCIAL PERFORMANCE OF COMMERCIAL BANKS IN NAIROBI CITY COUNTY, KENYA
}

\author{
${ }^{1}$ Janepher Dzine Mwamuye, \\ Master of Business Administration, Kenyatta University \\ ${ }^{2}$ Dr. Mary Ragui, \\ Lecturer, School of Business, Kenyatta University
}

\begin{abstract}
Purpose: In the Kenyan banking industry, the banks have adopted several strategies aimed at improving their competitive position in a highly competitive market. In reference to the aforementioned the general objective, this study specifically sought to examine how strategic alliances impact financial returns among Nairobi-based commercial banks. The current study specifically examined how brand marketing alliances, agency alliances, innovation alliances and technology alliances affect bank performance.
\end{abstract}

Methodology: This study was based on Transactional Cost, Control Power and Resource Based View theories. The study utilized descriptive research design, that targeted all 39 fully operational commercial banks in Nairobi. The unit of observation was the operations/ relationship manager and the finance manager across each commercial bank. The sample population consisted of 78 respondents. Census sampling was adopted to enhance representation of the respondents. Primary and secondary sources of data provided data which was then be analyzed in SPSS 23 using both descriptive and inferential statistics. The study employed means, standard deviation, correlation and regression methods of analysis, with results being presented using figures, tables and other infographics.

Results: An $85 \%$ response rate was received. The correlation results showed a positive and significant effect of brand marketing, agency, innovation and technological alliances on banks' profitability. The regression findings revealed that jointly brand marketing, agency, innovation and technological alliances predict $38.3 \%$ of shifts in profits generated by the banks. The study concluded that brand marketing alliances, agency alliances and technology alliances had a significant effect on profitability, while innovation alliances had an insignificant effect.

Unique contribution to theory, practice and policy: The study recommends that banks should constantly review their agency banking to ensure they are aligned to their financial goals. Lastly, commercial banks should strive to spur their research and development which can help drive their technological innovations.

Keywords: Brand Marketing Alliances, Agency Alliances, Innovation Alliances and Technological Alliances, Financial Performance 
Vol.6, Issue No. 4, pp 32-45, 2021

WwW.carijournals.org

\section{Introduction}

The emergence of Globalization coupled with the increase in competitive strategies has seen some of the biggest organizations implementing different strategies to increase survival chances. Mergers and acquisitions have become increasingly common with most organizations using these strategic alliances to strengthen their market positions and increase productivity (Nyatakyi \& Mouhamadou, 2015). Business organizations now have to strive to achieve and maintain sustained profitability and competitiveness. Indeed, transforming one's core competencies and leadership qualities to enhance long-term economic survival (Mwega \& Murinde, 2012). Modern organizations strive to remain competitive in the global markets, while considering the workplace relations to ensure that the employees are motivated to become innovative (Wilson, Casu, Girardone, \& Molyneux, 2010).

Pricewaterhouse Coopers (2015), established that there are several forces which are reshaping activities in banking institutions and they include technological capabilities, customer expectations, regulatory requirements, demographics and economic factors- which all create the need for strategic change. Pricewaterhouse Coopers (2015) studies further pointed out that given the emerging scenario, banks will need to choose what posture to adopt in order to manage to defensively deal with imminent change. They went on to conclude that winners of the future will have to innovate and transform themselves. Strategic alliances have been formed to facilitate entry into new markets and to reduce operational costs. Such relationships are usually established by two or more firms which may be from similar or different fields and locations of operation to offer a variety of distinct products and services (Wandia \& Ismail, 2018).

Strategic alliance are formal agreements between more than two companies for joint contribution of resources, sharing risks, and control (Samiee, 2008). This arrangement enables these partners to collectively achieve goals which could have been impossible to achieve without the formation of an alliance. Strategic alliances are the main mechanisms for achieving sustained competitiveness in the global business environment (Hsu \& Tang, 2010). Strategic alliance relationships remain to be the best business strategy which result in increasing the firm's competitive position in the global market. Hoffman, (2007) notes that strategic alliances are formed for varying reasons and are not limited to pursuing firms' financial returns. Makau (2012) pinions those strategic alliances function as formalized inter-organizational relationships that occurring between different firms that seek to gain a stronger foothold on the market, whether locally or internationally. These agreements are formed to increase the firm's competitive positioning through collaboration rather than competition (Kumar, 2014). In the current study strategic alliances was measured based on four main dimensions. The study reviewed the brand marketing alliance, the agency alliance, the innovation alliance and technology alliance within the banking sector in Kenya.

Letangule and Letting (2012) argue that increased technological innovation has improved operational efficiency. Financial institutions in developing economies have adopted, innovated and incorporated emerging technologies into their operations. Further, strategies such as employee recruitment and development strategies has led to acquisition of, and development of competent employees, who possess relevant skills and knowledge necessary for customer satisfaction and increased efficiency. This has improved the rate of revenue generation and customer retention. The acquisition of competent employees has increased the rate of innovation within financial institutions thus improving firm's operational capacity resulting in higher profits. Drucker (2013) and Quinn (2010) assert that technological innovations 
Vol.6, Issue No. 4, pp 32-45, 2021

occurring within commercial banks leads to increased functionality, thus increasing the ability of the bank to generate new sources of money.

Wambari (2009) notes that electronic banking innovation has improved banks' ability to increase product development, thus enhancing product and service offering, competitiveness, and management capability. Innovations such as direct ATM deposits, internet banking, and mobile banking has enhanced customer satisfaction levels, and improved the banks' internal management efficiency (Ombati, Magutu. S.M., Nyamwange, \& Nyaoga, 2011). According to Mwania and Muganda (2011), process innovation has been key to introducing new processes and operations in how banks operate, which has led to enhanced operational efficiency and transactions engaged by consumers. Process innovation in financial institutions includes improvements in Credit finance processing, customer processing, trade finance processing among others.

\section{Statement of Problem}

Strategic alliance is one of the most effective methods through which the bank can leverage its resources to generate profits hence increase the competitive stand of the bank (Ukpabio et al., 2016). These alliances in the banking industry are increasing as indicated by characteristics such as globalization, changes in service delivery, and customer demands (Ranft \& Marsh, 2008). The main competition in the banking industry is the rush to form partnerships with a range of companies including universities, retail shops and the government all to enhance customer satisfaction, reduce service delivery costs, increase the competitive position of the firm and to ensure penetration into emerging markets (Mwania \& Muganda, 2011). Despite the benefits and popularity of strategic alliances, few have been successful in some of their mandates. The rate of failure has been projected to stand at a high rate of $70 \%$. Within the Kenyan context, Yabs (2007) looked at the forms of strategic alliance within Equity bank that is market related and technology related. The researcher stated that market related alliances are more profitable for firms in the mature industry. Wandia and Ismail (2018) indicated that strategic alliances positively influence the financial performance of banks. Ndambuki (2016) concluded that agency banking and marketing alliances significantly improve bank performance. However, the available evidence is not conclusive. The existence of a knowledge gap makes this research essential in seeking to address the gap by assessing how certain strategic alliances impact financial viability of banks that carry out their business within Nairobi City County, Kenya.

\section{Objective of the Research}

To establish how strategic alliances relate to banks' financial performance in Nairobi City County in Kenya. The research specifically focused on;

i. To examine how brand marketing alliances impact financial performance among commercial banks within Nairobi City County, Kenya.

ii. To establish how agency alliances impact financial performance among commercial banks within Nairobi City County, Kenya.

iii. To determine how innovation alliances impact financial performance among commercial banks within Nairobi City County, Kenya.

iv. To examine how technology alliances impact financial performance among commercial banks within Nairobi City County, Kenya. 


\section{LITERATURE REVIEW}

\section{Theoretical Review}

The Transaction Cost Theory was proposed by Kogut (1988) who indicated that there are times when the markets will not function effectively due to external influences (Kogut, 1988). As a result, it becomes costlier to organize an exchange through the market than internally. Strategic alliances align several organizations together and as a result the partners to reduce the cost involved ensuring that the partners avoid opportunism (Beamish \& Banks, 1987). Hennart (1988), notes that the synergy arising from strategic partnerships are preferred to the synergies form alliances involving contractual obligations. Scholars assert that the TSC is effective when explaining how commercial banks adopt strategic alliances. Transaction costs are usually addressed when the structure of governance is being developed. The firms then form alliances with the aim of reducing costs and risk incurred (Saxena \& Bharadwaj, 2009). This theory was integral in linking brand market alliances and how they shape up the performance of Kenyan banks.

This resource-based view theory is a proponent of Penrose (1959) in the middle of $20^{\text {th }}$ century and is based on the principle that all companies have to obtain resources through interactions with the environment (McGahan, 2021). The theory focuses on the level of control over the available resources and states that if a firm has more power or control over resources then it is less vulnerable and increases its competitive power over other firms operating in the same environment. Competitive advantage can only be sustained by acquiring rare, extremely valuable, imperfectly imitable resources which have minimal substitutes (Lin, 2012). According to RBV, the inability to internally generate resources necessary for successful attainment of organization goals is an indication of the imperfection and mobility of resources. This forces the manager to engage with other players to improve access to resources skills, and competencies that the firm may lack at the moment, and use them to improve operational effectiveness. Alliances have been identified as the most effective strategy that all companies can adopt to increase access to these resources at an affordable price and in reasonable time without many constraints (Veilleux, Haskell, \& Pons, 2012). The theory was relevant in the current study in indicating how technology alliances can be relied on as a key resource that organizations can leverage to enhance bank performance.

\section{Empirical Review}

Mahtab and Abdullah (2016) examined a Bangladeshi bank to determine how marketing impacts returns of financial and banking products. The research adopted a case research design which was reliant on qualitative data which was analyzed through thematical analysis. Findings indicated that marketing of banking products was an intricate process that required a collaborative effort with other sectors within the economy such as telecommunication firms and insurance firms. This will help in raising awareness of the products as well as foster the growth of the market share of the bank and its' end financial gains. The study relied on a qualitative approach whereas the current study sourced data from primary and secondary sources, making is findings more detailed in assessing financial performance outcomes. Singh, Singh, and Sandhu (2017) examined strategies adopted by Indian banks to penetrate into new markets. The study adopted an exploratory research design with responses being obtained from the top managers within the commercial banks. Data analysis involved a mix of descriptive and inferential statistics. Findings revealed that collaboration between commercial banks and branding agencies enhanced their new market entry. Findings further showed that adoption of 
emerging technologies in new market entry strategies enhanced the competitiveness of the bank. The research failed to examine how marketing alliances influence banks' financial returns. Asiedu (2016) conducted research on the extent of use of market segmentation practices on performances of Colombian banks. Both data sources were used, and an exploratory design adopted. Analysis involved use of Herfindal Hirchman Index to test the causality between the variables. Findings showed that segmentation practices immensely affect performance of the chosen Colombian banks. Findings revealed that collaboration in marketing resulted in reduced operational marketing cost, expanded their market share and had better customer experience. The study involved Latin American banks whereas this study examined Kenyan banks.

Al-Jabri (2012) investigated the mobile banking penetration and adoption among Saudi Arabian banks. Adopting an exploratory case study research design, it was determined that although banks offered mobile banking options, the practice is yet to proliferate the country's culture since it is not compatible with consumers' requirements, lifestyles, and beliefs. Its impact has not been felt by players in the region's financial industry. However, the study noted that the introduction of mobile banking has seen an increase in the volume of banking transactions. The study did not examine how agency banking affects bank performance. Kambua (2015) investigated how agency banking impacts Kenyan banks profitability by adopting a descriptive research design. He used data from 16 commercial banks that had implemented agency banking as a market penetration strategy. Secondary data was sourced from annual reports published by the banks over a three-year period. From the data, it was clear that agent presence increased performance. The study showed that increased agency alliances fostered the deposits and withdrawal levels among commercial banks. The study only adopted secondary data in analysis, this research will involve both data sources to get the perspective of people who are involved in day-to-day operations in the banks. Onje and Oloko (2017) investigated the effect of strategic alliances on Kenyan banks' returns between 2013 and 2014. The study employed regression and correlation analysis in determination of how the variables are related. The study found a strong and positive link between strategic alliances and bank outcomes. The researchers noted that agency banking had contributed to a growth in banks' market share and branch network which all positively affected bank performance. The study relied on financial reports of 2013/2014 whereas current study examined the 2018 audited statements as the changing banking environment has adversely affected bank performance.

Goyal, Chawla, and Bhatia (2016) examined innovation as a growth strategy for banks. The study examined all the innovation that have been adopted within the Indian banking sector and examined the business growth $V$ is the 5-balance scorecard perspectives. The univariate analysis revealed that online banking has been adopted by large institutions and has led to increased operational efficiency and profitability. The research further indicated that adoption of new core banking solutions had contributed to increased service innovation and product innovations which fostered the growth of banks that had adopted their innovative capacities. The study considered commercial banks in India whereas current study examined commercial banks in Kenya. Kiptis and Wanyoike (2016) investigated the impact of bancassurance on returns among banks operating in Nakuru town, Kenya. A descriptive design was adopted and the study involved 180 finance-related employees working with eight banks that had integrated bancassurance strategies into their operations. The findings of the study indicated that competent management was innovative allowing for better strategic response to external changes, increasing performance. The study however did not consider other aspects of strategic 
Vol.6, Issue No. 4, pp 32-45, 2021

Www.carijournals.org

alliance such as agency and brand marketing alliances. Cherotich, Sang, Shisia and Mutung'u (2015) used secondary data in examining how financial innovations affect Kenyan banks' performance. Due to the small population, the study sought data from all banks in Kenya. It was revealed that financial innovation technologies significantly improve firms' financial returns. Further, it was determined that the innovative capacity of employees can expand the competitive edge of the financial institution. The study however focused only on financial innovation and failed to examine other innovation alliances such as product and service innovation.

Charles and Gapaya (2018) examined how technological alliance impacted performance of Rwandan microfinance institutions. The study targeted 491 SMEs but using Slovin's formula, 220 were chosen. The study relied on both descriptive and inferential statistics, with findings showing that technology alliance is significantly correlated to performance of microfinance banks $(r=0.518, p<0.01)$. The researchers indicated that research and development and the technological transfer within the MFI's contributed significantly to the institutional performance. This study investigated performance within MFI's, the current focused on commercial banks. Ngugi and Karina (2013) looked into technological innovation and its impact on bank outcomes in Nairobi. The researchers adopted a descriptive research design which relied on descriptive and inferential analyses in data analysis. Conclusions were that mobile banking has enabled the development of new products and services which are useful in establishing competitive advantage, and market repositioning.

\section{Research Methodology}

A descriptive research design was used due to its ability to ask questions of who, what, when, where, and how certain factors are related to the research problem. Descriptive research describes "what exists" while considering the situational external and internal factors. The research utilized both qualitative and quantitative data to provide a comprehensive view of the research question. According to CBK (2020), Kenya has 41 registered commercial banks, with two banks under receivership (Imperial Bank and Chase Bank Kenya). The research did not include the banks under receivership thus the target population consisted of 39 operational and registered banks operating in Nairobi City County. The current study carried out a census survey involving all respondents from the 39 operational commercial banks. The unit of observation was the operations/relationship manager and the finance manager within each bank. The respondents have the requisite knowledge on the strategic alliances and financial performance of their respective banks hence the information availed was key to solving the research problem. The sample size consisted of 78 respondents.

The researcher collected primary research data which was utilized in solving the study problem. The research adopted a structured questionnaires with a 5-point Likert scale of measurement. The research further reviewed secondary data sources such as journals and reports in development of the research report. Permission was sought from the university's graduate school, the national research institute (NACOSTI) and from the banks prior to embarking on the data collection. Research assistants were utilized as the study involved the drop and pick method. Data analysis is key to determining the extent of the relationship between the study variables. The researcher utilized both descriptive and inferential analysis and adopted SPSS 23 for coding. Frequency distribution, measures of central tendency and measures of variability was used to determine the relationships between the variables. Correlation and inferential analysis were used to analyze inferential statistics. 


\section{Results and Discussion}

The study was conducted during the period March to May 2021. As results of the continued restrictions imposed by the government the research relied on Microsoft Teams, Google forms and Physical Questionnaires in the data collection process. The sample respondents were 78 officials within the banks that are fully operational in Kenya as guided by Central Bank of Kenya directory of December 2020. The research was able to obtain 66 responses from the targeted 78 officials which was an $85 \%$ response rate. This was considered representative of the study sample hence was deemed suitable for quantitative analysis and making statistical inferences.

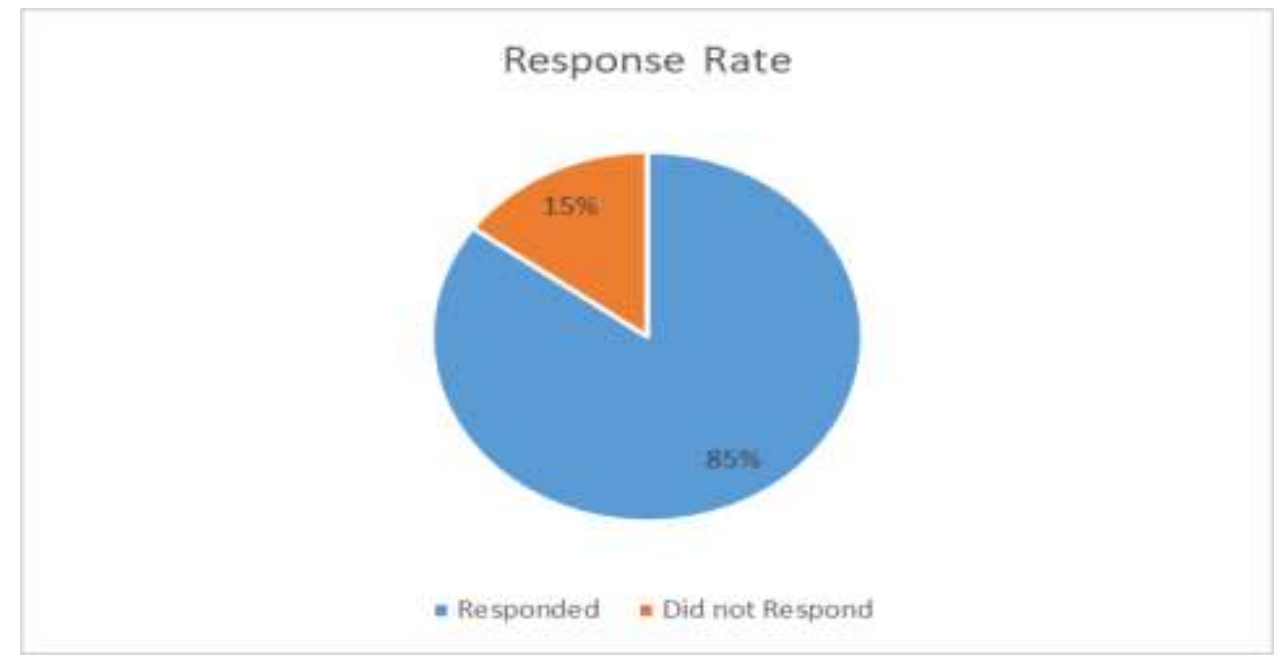

Figure 1 Response Rate

Source: Field data (2021)

The study reviewed the respondents' position in the bank, with findings indicating that most of the respondents $49 \%(n=32)$ were relationship managers, $35 \%(n=23)$ operations manager and $16 \%(\mathrm{n}=11)$ finance managers. This was an indication that the participants held senior management positions that are aware of the alliances adopted in the banks as well as the performance of the institutions.

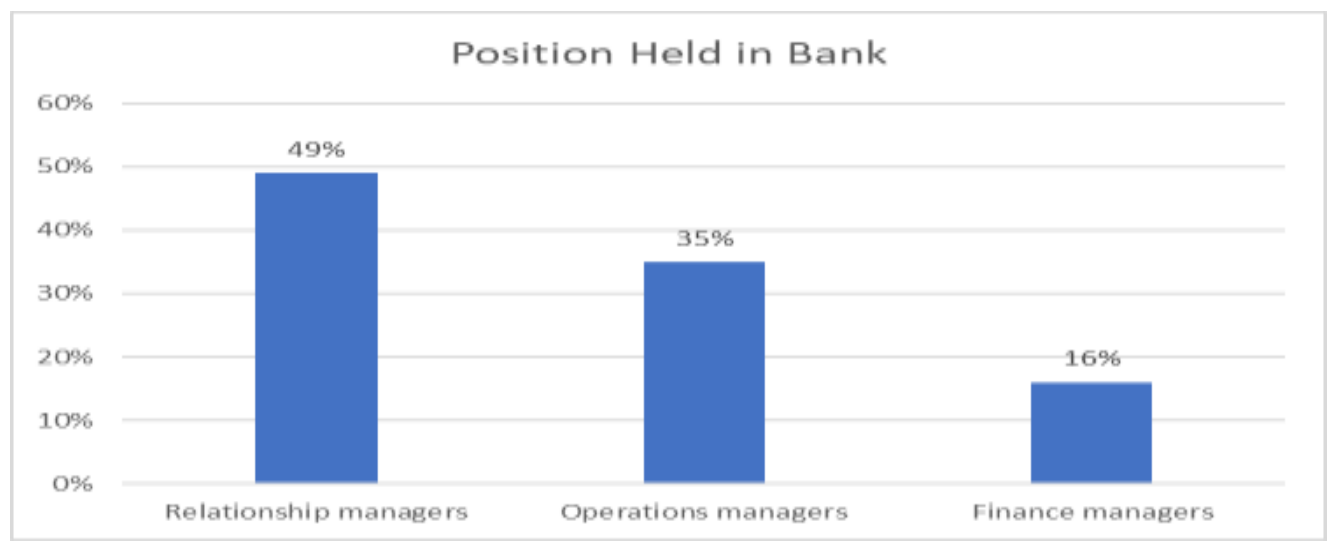

Figure 2 Position held in Commercial Bank

Source: Research Data (2021) 
Journal of Business and Strategic Management

ISSN 2520-0402 (Online)

Vol.6, Issue No. 4, pp 32-45, 2021

WwW.carijournals.org

\section{Correlation Analysis}

The study utilized correlation analysis to determine the direction of the relationship between the independent variables and the financial performance of the commercial banks. The correlation tests were conducted at $5 \%$ significance level using a one-tailed test.

\section{Table 1 Correlation Tests}

\begin{tabular}{|c|c|c|c|c|c|c|}
\hline & & $\begin{array}{c}\text { Financial } \\
\text { Performance }\end{array}$ & $\begin{array}{c}\text { Brand } \\
\text { Marketing } \\
\text { Alliances }\end{array}$ & $\begin{array}{l}\text { Agency } \\
\text { Alliances }\end{array}$ & $\begin{array}{l}\text { Innovation } \\
\text { Alliances }\end{array}$ & $\begin{array}{c}\text { Technology } \\
\text { Alliances }\end{array}$ \\
\hline \multirow[t]{3}{*}{$\begin{array}{l}\text { Financial } \\
\text { Performance }\end{array}$} & $\begin{array}{l}\text { Pearson } \\
\text { Correlation }\end{array}$ & 1 & & & & \\
\hline & Sig. (1-tailed) & & & & & \\
\hline & $\mathrm{N}$ & 66 & & & & \\
\hline \multirow[t]{3}{*}{$\begin{array}{l}\text { Brand Marketing } \\
\text { Alliances }\end{array}$} & $\begin{array}{l}\text { Pearson } \\
\text { Correlation }\end{array}$ & $.521^{* *}$ & 1 & & & \\
\hline & Sig. (1-tailed) & .000 & & & & \\
\hline & $\mathrm{N}$ & 66 & 66 & & & \\
\hline \multirow[t]{3}{*}{ Agency Alliances } & $\begin{array}{l}\text { Pearson } \\
\text { Correlation }\end{array}$ & $.571^{* *}$ & $.620^{* *}$ & 1 & & \\
\hline & Sig. (1-tailed) & .000 & .000 & & & \\
\hline & $\mathrm{N}$ & 66 & 66 & 66 & & \\
\hline \multirow[t]{3}{*}{$\begin{array}{l}\text { Innovation } \\
\text { Alliances }\end{array}$} & $\begin{array}{l}\text { Pearson } \\
\text { Correlation }\end{array}$ & $.221^{*}$ & $.560^{* *}$ & $.331^{* *}$ & 1 & \\
\hline & Sig. (1-tailed) & .037 & .000 & .003 & & \\
\hline & $\mathrm{N}$ & 66 & 66 & 66 & 66 & \\
\hline \multirow[t]{3}{*}{$\begin{array}{l}\text { Technology } \\
\text { Alliances }\end{array}$} & $\begin{array}{l}\text { Pearson } \\
\text { Correlation }\end{array}$ & $.232^{*}$ & .173 & $.337^{* *}$ & $.291^{* *}$ & 1 \\
\hline & Sig. (1-tailed) & .031 & .083 & .003 & .009 & \\
\hline & $\mathrm{N}$ & 66 & 66 & 66 & 66 & 66 \\
\hline
\end{tabular}

Source: Research Data (2021)

The study indicated that brand marketing alliances have a moderate positive and significant effect on the financial performance of the commercial banks $(r=.521$, Sig $=.000<.05)$. Mahtab 
Vol.6, Issue No. 4, pp 32-45, 2021

Www.carijournals.org

and Abdullah (2016) revealed that improved marketing and branding of banking products is linked to better growth in market share and financial gains. Singh, Singh, and Sandhu (2017) also noted that branding agencies and new market entry strategies have led to significant changes in the competitiveness of commercial banks. The results also established there is a moderate positive and significant effect of agency alliances on the financial performance of the commercial banks $(r=.571, \mathrm{Sig}=.000<.05)$. The results resonate with Al-Jabri (2012) who revealed that introduction of mobile banking and proliferation of agency banks has enhanced the volume of banking transactions. Kambua (2015) also showed that increased adoption of agency alliances has led to better deposits and withdrawal levels among commercial banks.

The findings indicated that innovation alliance has a weak but positive impact on banks' financial returns $(r=.221$, Sig $=.037<.05)$. Goyal, Chawla, and Bhatia (2016) revealed that utilization of innovations such as online banking, digital platforms and change sin core banking solutions led to better growth and profitability within commercial banks. Kiptis and Wanyoike (2016) noted that innovative practices resulted in improved bank performance in Kenya. Technology alliances were also determined to have a weak positive and significant effect on banks' profitability $(\mathrm{r}=.232$, Sig $=.031<.05)$. Charles and Gapaya $(2018)$ found out that technology alliance is significantly correlated to performance of microfinance banks.

\section{Regression Analysis}

A multiple linear regression model was used in estimating the magnitude of the relationship between the dependent and independent variables. The results are presented in this section.

Table 2 Regression Summary

\section{Model Summary}

\begin{tabular}{lc|c|c|c|c} 
Model & $\mathrm{R}$ & R Square & $\begin{array}{c}\text { Adjusted R } \\
\text { Square }\end{array}$ & $\begin{array}{c}\text { Std. Error of the } \\
\text { Estimate }\end{array}$ & Durbin-Watson \\
\hline 1 & $.619^{\mathrm{a}}$ & .383 & .342 & 2.53795 & 1.927 \\
\hline
\end{tabular}

a. Predictors: (Constant), Technology Alliances, Brand Marketing Alliances, Innovation Alliances, Agency Alliances

b. Dependent Variable: Financial Performance

The analysis showed an (R2) as 0.383 which shows that $38.3 \%$ of financial performance of commercial banks can be predicted by the strategic alliances measured by; technology alliances, brand marketing alliances, innovation alliances and agency alliances.

Table 3 ANOVA Summary

\begin{tabular}{llc|c|c|c|c}
\hline Model & & Sum of Squares & df & Mean Square & F & Sig. \\
\hline 1 & Regression & 243.709 & 4 & 60.927 & 9.459 & $.000^{\mathrm{b}}$ \\
\cline { 2 - 7 } & Residual & 392.912 & 61 & 6.441 & & \\
\hline & Total & 636.621 & 65 & & & \\
\hline
\end{tabular}

a. Dependent Variable: Financial Performance 
Journal of Business and Strategic Management

ISSN 2520-0402 (Online)

Vol.6, Issue No. 4, pp 32-45, 2021

WwW.carijournals.org

b. Predictors: (Constant), Technology Alliances, Brand Marketing Alliances, Innovation Alliances, Agency Alliances

The findings of the ANOVA analysis yielded a P-value of .000 which is less than the critical value of .05 , further the F-calculated was 9.459 which indicated there is a statistically significant relationship between strategic alliances and the financial performance of the commercial banks. Thus, the null hypothesis is rejected in favor of the alternate.

Table 4 Regression Coefficients

\begin{tabular}{|c|c|c|c|c|c|}
\hline \multirow[b]{2}{*}{ Model } & \multicolumn{2}{|c|}{$\begin{array}{l}\text { Unstandardized } \\
\text { Coefficients }\end{array}$} & \multirow{2}{*}{$\begin{array}{c}\text { Standardized } \\
\text { Coefficients } \\
\text { Beta }\end{array}$} & \multirow[b]{2}{*}{$\mathrm{t}$} & \multirow[b]{2}{*}{ Sig. } \\
\hline & $\mathrm{B}$ & Std. Error & & & \\
\hline 1 (Constant) & 4.317 & 4.346 & & .993 & .324 \\
\hline Brand Marketing Alliances & .389 & .167 & .344 & 2.321 & .024 \\
\hline Agency Alliances & .311 & .114 & .369 & 2.733 & .008 \\
\hline Innovation Alliances & -.111 & .119 & -.118 & -.936 & .353 \\
\hline Technology Alliances & .139 & .059 & .082 & 2.356 & .006 \\
\hline
\end{tabular}

a. Dependent Variable: Financial Performance

From the above results the final regression model can be stated as follows;

$$
Y=4.317+.389 X_{1}+.311 X_{2}+-.111 X_{3}+.139 X_{4}+4.346
$$

Based on the regression coefficient results $\left(\beta_{1}=.389\right.$, Sig $\left.=.024<.05\right)$. These findings indicated that brand marketing alliances have a positive and significant influence on financial performance. Thus, a change in brand marketing alliances will yield a .389 change in the financial performance among commercial banks. These findings are consistent with Asiedu (2016) who indicated that collaboration in marketing, expansion in market share and operational marketing enhanced bank performance. Based on the regression coefficient results $\left(\beta_{2}=.311, \mathrm{Sig}=.008<.05\right)$. These findings indicated that agency alliances have a positive and significant influence on the financial performance. Thus, a change in agency alliances will yield a .311 change in the financial performance among commercial banks. The results resonate with Onje and Oloko (2017) who concluded that agency banking had contributed to a growth in banks' market share and branch network.

Based on the regression coefficient results $\left(\beta_{3}=-.111\right.$, Sig $\left.=.353>.05\right)$. These findings indicated that innovation alliances have a positive and insignificant influence on profitability. These findings are not consistent with Cherotich, Sang, Shisia and Mutung'u (2015) who indicated that financial innovation and financial returns had a positive and significant relationship. Based on the regression coefficient results $\left(\beta_{4}=139\right.$, Sig $\left.=.006<.05\right)$. These findings indicated that technology alliances have a positive and significant influence on the 
financial performance. Thus, a change in technology alliances will yield a .139 change in the financial performance among commercial banks. Ngugi and Karina (2013) made similar conclusions when they indicated that new product and service development is key to improving the competitive position of banks.

\section{Conclusions}

Regression analysis findings concluded that strategic alliances significantly improve commercial bank returns. The findings revealed that jointly brand marketing, agency, innovation and technological alliances predict $38.3 \%$ of the variations in bank returns. The results further support the conclusion that brand marketing alliances significantly improve banks' financial performance. Findings ascertained that improving brand marketing, entry into new markets, better marketing promotions, utilization of social media marketing strategies and concentrating on a particular market niche can improve bank returns.

The findings also show a positive and significant effect of agency alliances on banks' financial outcomes. The analysis pointed out that having a better network of agency banking outlets, tapping into point-of-sale services, bancassurance, mobile branches and improving strategic partnerships can lead improve firm returns. The findings further show that innovation alliances do not significantly impact banks' financial performance. Lastly, based on the results the research concludes that technological alliances significantly improve firm profits. The findings indicated that embracing mobile technologies, improving automation of bank systems, upgrading the core banking solution, cashless banking systems and utilization of digital applications can be vital to enhancing bank profits.

\section{Recommendations}

The study recommends that banking firms should expand the capacity of their digital marketing teams as well as support digitalization of their marketing strategies as this will enhance market innovations. The study further recommends that the banks should invest in new core infrastructure that will foster the technical innovation. The study further recommends that the banks should re-evaluate their marketing tools deployed within the firm which will help in improving effectiveness of marketing tools. This can be undertaken through better market segmentation and product provision in the banking industry. The study further recommends that the banks should recruit competent managers who can help to guide operational strategies execution within the banks to support better growth. The study further recommends that commercial banks should recruit agencies that can help expand their network in areas that are not well-served by digital banking solutions. This will ensure commercial banks don't get into agencies that do not yield any financial returns to the commercial banks. The study recommends that the firms should develop clear policies to guide their adoption of various technologies and ecommerce platforms that can help in enhancing the efficiency of the firms in service offering and increasing business capacity. Commercial banks should also expand their technological capacity by increasing their investments towards development of new core solutions that will drive operational efficiency and lead to better financial returns.

\section{References}

Al-Jabri, I. M. (2012). Mobile banking adoption: application of diffusion of innovation theory,. Journal of Electronic Commerce Research, , Vol 13, No 4, pp 40-62. 
Journal of Business and Strategic Management

ISSN 2520-0402 (Online)

Vol.6, Issue No. 4, pp 32-45, 2021

WwW.carijournals.org

Asiedu, E. (2016). A Study of Use and Impact of Market Segmentation Practices on Bank Performance. With Special Reference to Commercial Banks in Colombia. . Journal of Business \& Financial Affairs, 5(162), 2167-0234.

Beamish, P. W., \& Banks, J. C. (1987). Equity joint ventures and the theory of the multinational enterprise. . Journal of international business studies, 18(2), 1-16.

CBK. (2020). The Kenya Financial Sector Stability Report. Nairobi, Kenya: Central Bank of Kenya.

Charles, N., \& Gapaya, S. (2018). Effect Of Technological Alliance On The Performance Of Microfinance Institution In Rwanda. . European Journal of Business and Social Sciences, , 7(03), 19-36.

Cherotich, K. M., Sang, W., Shisia, A., \& Mutung'u, C. (2015). Financial innovations and performance of commercial banks in Kenya. . International Journal of Economics, Commerce and Management , (5), 1242-1265.

Drucker, P. (2013). Empirical studies of innovation activity. In Handbook of the Economics of Innovation and Technological Changes. Paul Stoneman, ed. Cambridge; Blackwell.

Goyal, S., Chawla, D., \& Bhatia, A. (2016). Innovation: Key To Improve Business Growth Of Banking Industry. International Journal of Advances in Engineering \& Technology, , 9(3), 331.

Hennart, J. F. (1988). A transaction costs theory of equity joint ventures. . Strategic management journal, 9(4), 361-374.

Hoffman, W. (2007). Strategies for managing a portfolio of alliances. . Strategic Management Journal, , 28: 827-856.

Hsu, H. H., \& Tang, J. W. (2010). A model of marketing strategic alliances to develop longterm relationships for retailing. . International Journal of Business and Information, $5(2)$.

Kambua, D. B. (2015). The effect of agency banking on financial performance of commercial banks in Kenya. . MBA Thesis University of Nairobi.

Kiptis, K. K., \& Wanyoike, D. (2016). Influence of Bancassurance on Financial Performance of Commercial Banks in Nakuru Town, Kenya. . International Journal of Research in Business Management, , 4(4), 19-30.

Kogut, B. (1988). A study of the life cycle of joint ventures. . Management International Review, 28(4), 39-52.

Kumar, R. (2014). Managing ambiguity in strategic alliances. University of California, Berkeley, , 56(4), 82-103.

Letangule, S., \& Letting, N. (2012). Innovation Strategies at Standard Charted Bank Kenya,. International Journal of management and Business Studies, , 2(3): 75-78. 
Journal of Business and Strategic Management

ISSN 2520-0402 (Online)

Vol.6, Issue No. 4, pp 32-45, 2021

WwW.carijournals.org

Lin, H. (2012). Strategic alliances for environmental improvements. . Business \& Society, 51(2), 335-348.

Mahtab, N., \& Abdullah, M. (2016). Marketing of Financial and Banking Products: An Example from Bangladeshi Bank. Journal of Accounting and Marketing, 5:159. doi: 10.4172/2168-9601.1000159.

Makau, D. (2012). Strategic alliances and organizational competitiveness among commercial banks in Kenya: A case study of Kenya Commercial Bank. . University of Nairobi.

McGahan, A. M. (2021). Integrating insights from the resource-based view of the firm into the new stakeholder theory. . Journal of Management, 0149206320987282.

Mwania, M., \& Muganda, N. (2011). An Investigation on the Relationship Between Information Technology Conceptualization and Bank Performance. School of Computer Science \& Information Technology, Kimathi University College.

Mwega, F., \& Murinde, V. (2012). Regulatory Reforms and their Impact on the Competitiveness and Efficiency of the Banking Sector: A Case Study of Kenya. In Bank Regulatory Reforms in Africa. Palgrave MacMillan.

Ndambuki, D. (2016). The effect of agency banking on profitability of commercial banks in Kenya. . PhD diss., University of Nairobi.

Ngugi, K., \& Karina, B. (2013). Effect of innovation strategy on performance of commercial banks in Kenya. . International Journal of Social Sciences and Entrepreneurship, 1(3), 158-170.

Nyatakyi, E., \& Mouhamadou, S. (2015). The Banking System in Africa: Main Facts and Challenges: . Africa Economic Brief, , 6(5).

Ombati, R., Magutu. S.M., Nyamwange, N., \& Nyaoga, P. (2011). Technology and Service Quality in the Banking Industry: Importance and Performance of various factors considered in Electronic Banking Services, . African Journal of Business \& management, , 1(4): 151-164.

Onje, F., \& Oloko, D. (2017). Influence of strategic alliance on financial performance of commercial banks in Kenya. PhD Dissertation JKUAT.

Pricewaterhouse Coopers. (2015). Retail Banking 2020. .

Quinn, D. (2010). Bank Efficiency and Competition in Low-Income Countries: The Case of Uganda. International Monetary Fund Working Paper, WP/05/240.

Ranft, A., \& Marsh, S. (2008). Accessing knowledge through acquisitions and alliances: An empirical examination of new market entry. . Journal of Managerial Issues, , 20: 5167.

Samiee, S. (2008). Global marketing effectiveness via alliances and electronic commerce in business-to-business markets,. Industrial Marketing Management, 37(1), 3-8. 
Vol.6, Issue No. 4, pp 32-45, 2021

Www.carijournals.org

Saxena, K., \& Bharadwaj, S. S. (2009). Managing business processes through outsourcing: a strategic partnering perspective. . Business Process Management Journal, , 687-715.

Singh, D., Singh, H., \& Sandhu, N. (2017). New Market Entry Strategies: Public and Private Sector Banks in India. . SCMS Journal of Indian Management, , 14(1).

Ukpabio, M. G., Olaposi, T., \& Siyanbola, W. O. (2016). Technology acquisition and technology learning in banking industry: Lessons from Nigerian banking sector. . African Journal of Business Management, , 10(20), 511-521.

Veilleux, S., Haskell, N., \& Pons, F. (2012). Going global: how smaller enterprises benefit from strategic alliances. . Journal of Business Strategy, , 33(5), 22-31.

Wambari, P. (2009). Mobile Banking in developing countries: A case study of Kenya, Unpublished Masters' Thesis, Vaasan Ammattikorkea Koulu.

Wandia, W. M., \& Ismail, N. O. (2018). Effects Of Strategic Alliances On Performance Of Commercial Banks In Kenya: A Case Of Kenya Commercial Bank Limited. International Journal of Business Management \& Finance , 1(58): 986-1001, 2018.

Wilson, J., Casu, B., Girardone, C., \& Molyneux, P. (2010). Emerging themes in banking: Recent literature and directions for future research; . The British Accounting Review, 42 (2010). 